\title{
Ecology and biology of the lake sturgeon: a synthesis of current knowledge of a threatened North American Acipenseridae
}

\author{
Douglas L. Peterson · Paul Vecsei • \\ Cecil A. Jennings
}

Received: 6 June 2006/ Accepted: 9 October 2006/Published online: 14 November 2006

(C) Springer Science+Business Media B.V. 2006

\begin{abstract}
The lake sturgeon is one of the largest North American freshwater fish and was once common in most inland rivers and lakes of the US and Canadian Midwest. World demand for caviar and sturgeon meat led to a dramatic decline of lake sturgeon populations throughout much of its range. Along with overfishing, lake sturgeon populations have been negatively affected by habitat degradation. Recruitment factors and early life history are poorly understood. Today, renewed interest in lake sturgeon restoration has led to numerous state and federally-funded research activities. Research has focused on identifying and assessing the size structure of remnant stocks, the availability of spawning habitat, and factors affecting reproductive success. Additional studies are needed to improve hatchery techniques, to better understand recruitment mechanisms, and how genetic diversity
\end{abstract}

\section{L. Peterson $(\varangle) \cdot$ P. Vecsei}

Fisheries Division, Warnell School of Forestry and Natural Resources, University of Georgia, Athens, GA 30602, USA

e-mail: dpeterson@warnell.uga.edu

C. A. Jennings

US Geological Survey, Georgia Cooperative Fish and Wildlife Research Unit, Warnell School of Forestry and Natural Resources, University of Georgia,

Athens, GA 30602, USA among and within meta-populations may affect long-term recovery of depleted populations.

Keywords Biology $\cdot$ Ecology $\cdot$ Habitat $\cdot$ Lake sturgeon $\cdot$ Life history

\section{Introduction}

The lake sturgeon (Acipenser fulvescens, Acipenseridae) is a large, cartilaginous, benthic fish, endemic to larger mesotrophic and oligotrophic systems of the Central US, Great Lakes, and the Hudson Bay drainages of Canada. Its life history, characterized by long life span, late age-at-maturity, and protracted spawning periodicity, is unique among North America's freshwater fishes (Harkness and Dymond 1961; Scott and Crossman 1973; Becker 1983). Although once abundant throughout their range, severe overfishing in the late 1800 s and early 1900 s decimated most populations (Auer 1999, 2004; Bogue 2000). Today, few healthy populations remain and many anthropogenic factors continue to hamper most conservation and restoration efforts (Noakes et al. 1999; Auer 2004; Wilson and McKinley 2004). Among these factors, hydroelectric dams that obstruct upstream access to historic spawning grounds and degrade critical downstream habitats, are the most problematic (Auer 1996a; Wilson and McKinley 2004). Currently, the lake sturgeon is 
listed as extirpated, endangered, threatened or of special concern in 12 states (Leonard et al. 2004; Holey and Trudeau 2005).

The unique appearance and life history of the lake sturgeon has generated considerable interest among many fisheries scientists. Since 1989, five separate international symposia have focussed on the biology and management of lake sturgeons and other imperilled sturgeons. As many fisheries managers have become increasingly concerned with the conservation of endemic species in recent years, renewed interest in lake sturgeon has spurred several new research or restoration initiatives. Although these and many previous studies have improved our knowledge of lake sturgeon life history and population dynamics, the phylogeny of all sturgeon species, including that of lake sturgeon, remains unclear. In this paper, we describe several key taxonomic characters of lake sturgeon as they relate to sturgeon phylogeny. Furthermore, we synthesize existing studies of life history as well as current population status and management efforts.

\section{Taxonomy and systematics}

The oldest sturgeon fossils date back to the Upper Cretaceous; however, the earliest members of the group probably evolved in the Lower Jurasic approximately 200 million years ago (Bemis et al. 1997). Although sturgeon phylogeny still remains somewhat uncertain, most taxonomists agree that Acipenseriformes is a monophyletic group, derived from the paleonisciform fishes (Bemis et al. 1997). In recent years however, ichthyologists have developed conflicting theories regarding phylogenetic relationships within the group, particularly within the Acipenser genus. For example, Birstein et al. (2002) questions the monophyly of the group and claims that current members of the genus do not share a single synapomorphic molecular character, which suggests multiple evolutionary lineages. Findeis (1997) proposed a similar argument noting the absence of shared osteological characters within the genus. Regardless, investigators have noted an array of common morphological characters shared by all members of the genus including: a disconnected gill membrane attached at the isthmus; a small, downward-projecting transverse mouth; a long flattened snout that is either conical or narrow; a set of 4 cylindrical or fimbrated barbels; a palatoquadratum connecting the symplecticum; a stylohyale articulating with the posterior section of the symplecticum; a linear arrangement of the palatoquadratum and the upper part of the maxillae; and clustered basihyalia positioned along the median line of the rostrum. (Antoniu-Murgoci 1936a, b, 1942).

Regardless of phylogenetic uncertainties, the sturgeon family (Acipenseridae) is comprised of 27 species distributed among four separate genera. The largest of these, Acipenser, contains 17 species, five of which are native to North America (Scott and Crossman 1973; Grande and Bemis 1996; Bemis and Kynard 1997; Findeis 1997). Among Acipenser species, only the lake sturgeon completes its lifecycle entirely within freshwater. As such, its evolutionary history and relationship among other members of the genus has been of particular interest to many sturgeon researchers.

Ontogenetic changes in lake sturgeon morphology have prompted many early investigators to suggest that $A$. fulvescens is actually composed of several discrete species (Harkness and Dymond 1961; Priegel and Wirth 1971). During the 19th and early 20th centuries, at least 17 different scientific names have been assigned to the various Acipenser populations of the Great Lakes, St. Lawrence River, and Central US (Scott and Crossman 1973). By the 1950s however, ichthyologists had determined that these stocks all belonged to a single species. Following the rules of nomenclature, the oldest scientific designation, Acipenser fulvescens (Rafinesque 1817), has since been accepted as the official species name.

\section{Morphology}

\section{General description}

'The stud-like bones are most beautiful objects, being as hard or harder than ivory, with the outer surface indented and marked as though they had been carved by a Japanese artist. When set in silver, selected 
samples of these shackles form very beautiful ornaments for ladies' dresses, and I certainly would advise my lady readers who are always looking for something new and pretty to try the effect of sturgeon's shackles when worn as ornaments.'

—Frank Buckland (1883), Natural History of British Fishes.

The physical appearance of lake sturgeon (Fig. 1) is similar to that of most other Acipenser species; and like all other members of the genus, they are easily recognized by several primitive morphological features that distinguish them from other North American fishes. Perhaps the most noticeable of these is the scaleless body, which is protected by five lateral rows of bony plates or scutes. The heavy-set body is spindle shaped, the greatest body depth occurring slightly anterior to the midsection. The origin of the anal fin is located posterior to that of the dorsal, its tip rarely extending beyond the caudal fulcrate plate. Other morphological features that distinguish lake sturgeon from other North American freshwater fishes include a heavily armoured skull, a spiral valve intestine, and a cellular swim bladder that retains some of the lung-like characteristics of early actinopterigeans (Harkness and Dymond 1961).

Basic morphology of the lake sturgeon is similar to that of other Acipenserids. The elongated body in cross-section is pentagonal in young juvenile specimens but becomes progressively more rounded with age (Scott and Crossman 1973). Dorsal, lateral, and ventral scute counts are typically 9-17, 29-42, and 7-12, respectively. Dorsal fin rays number 35-45; anal fin rays 25-30 (Vladykov and Greeley 1963; Scott and Crossman 1973). The slightly upturned rostrum is disproportionately large in juveniles, often exceeding post-orbital distance in juveniles $<50 \mathrm{~cm}$; however, this proportion is gradually reversed with age (Vladykov and Greeley 1963).

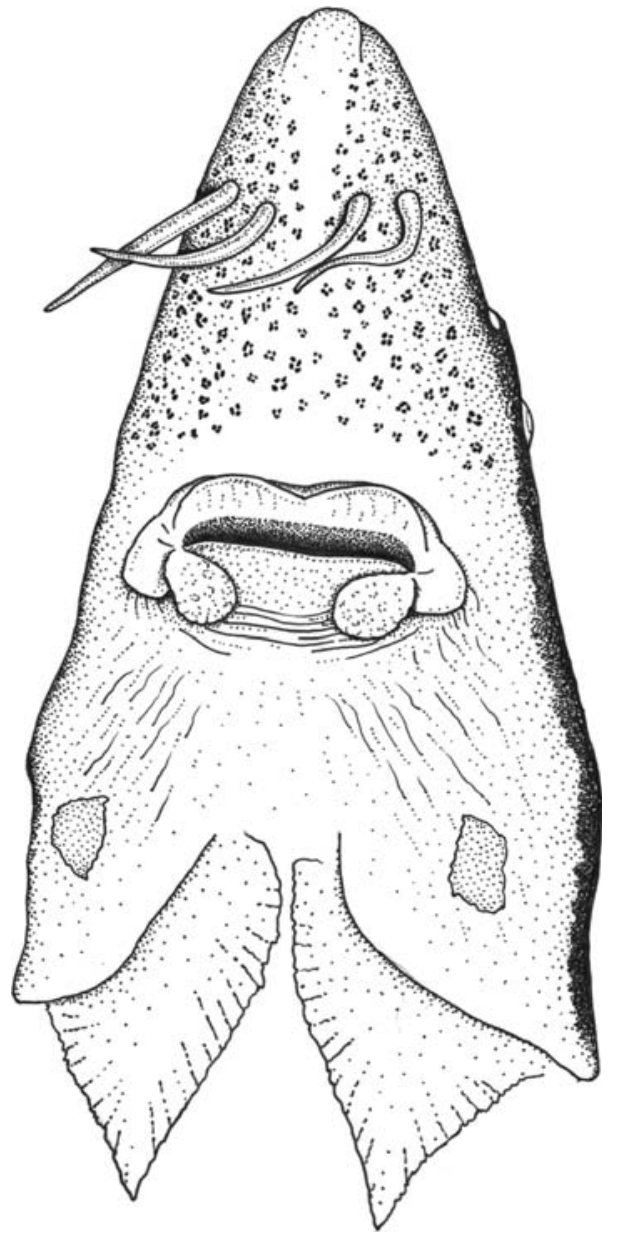

Fig. 2 Ventral view of lake sturgeon head, showing distribution of sensory pits and relative position of barbels and mouth

The large, transverse mouth typically measures approximately $66-93 \%$ of the interorbital width (Vladykov and Greeley 1963). The top lip is continuous; the bottom lip interrupted (Fig. 2). Mouth shape and size in proportion to head width is most similar to that of shortnose sturgeon $(A$. breviostrum) (Vladykov and Greeley 1963; Hochleitner and Vecsei 2004). As in the elasmobranches, the sturgeon jaw is detached from the skull,

Fig. 1 Basic morphology of the adult lake sturgeon

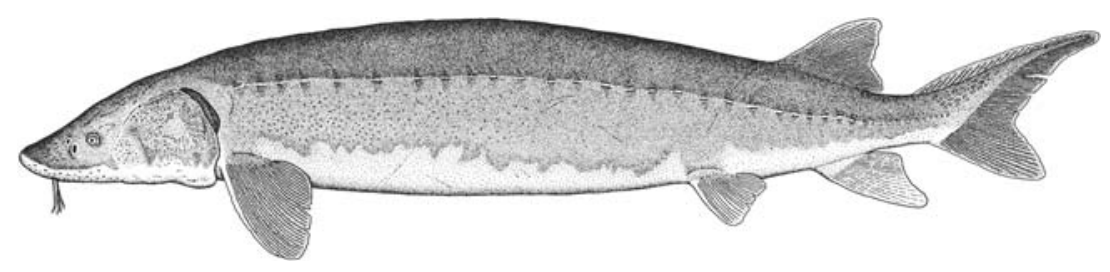


allowing the mouth to project downward during feeding (Vecsei and Peterson 2004). Lake sturgeon barbels are situated closer to the tip of the snout than to the origin of the mouth-an important diagnostic character distinguishing the species from acipenserids. Gill rakers are short and typically number 25-40 (Vladykov and Greeley 1963). The thick-walled, gizzard-like stomach is connected to a spiral-valve intestine, a primitive alimentary arrangement shared by many Acipenserids adapted to a diet of benthic crustaceans and molluscs (Harkness and Dymond 1961).

Body armouring is extensive on juveniles but becomes progressively reduced with age (Priegel and Wirth 1971; Scott and Crossman 1973; Vecsei and Peterson 2004). In juveniles $<100 \mathrm{~cm}$, the laterodorsal and lateroventral surfaces are protected by a layer of tightly-spaced denticles evenly distributed between the five principal rows of scutes. Sharp, apical hooks are particularly prominent on the scutes of juveniles, but these gradually disappear with age until the scutes themselves are almost completely resorbed later in adulthood (Fig. 3). In contrast, most anadromous sturgeons retain ossified scutes that continue to grow throughout their entire lifecycle. Hence, the process of scute resorbtion in adult lake sturgeon probably illustrates an important trade-off in the functional morphology of body armouring within the genus. In freshwater environments devoid of sharks and other large biting predators, the protective advantage of body amour diminishes with increasing body size, yet the energetic costs of overcoming frictional drag caused by the rough armoured surfaces increases exponentially. By adulthood, lake sturgeon have simply outgrown all potential aquatic predators and hence, their need for body armouring.

The skull of all acipenserids, including the lake sturgeon, is heavily armoured by a series of contiguous bony plates that are most apparent in juveniles and sub-adults (Fig. 4). Variation and complexity in the ossification of the Acipenser skull roof has been noted by several researchers
Fig. 3 Ontogenetic changes is body armouring of lake sturgeon
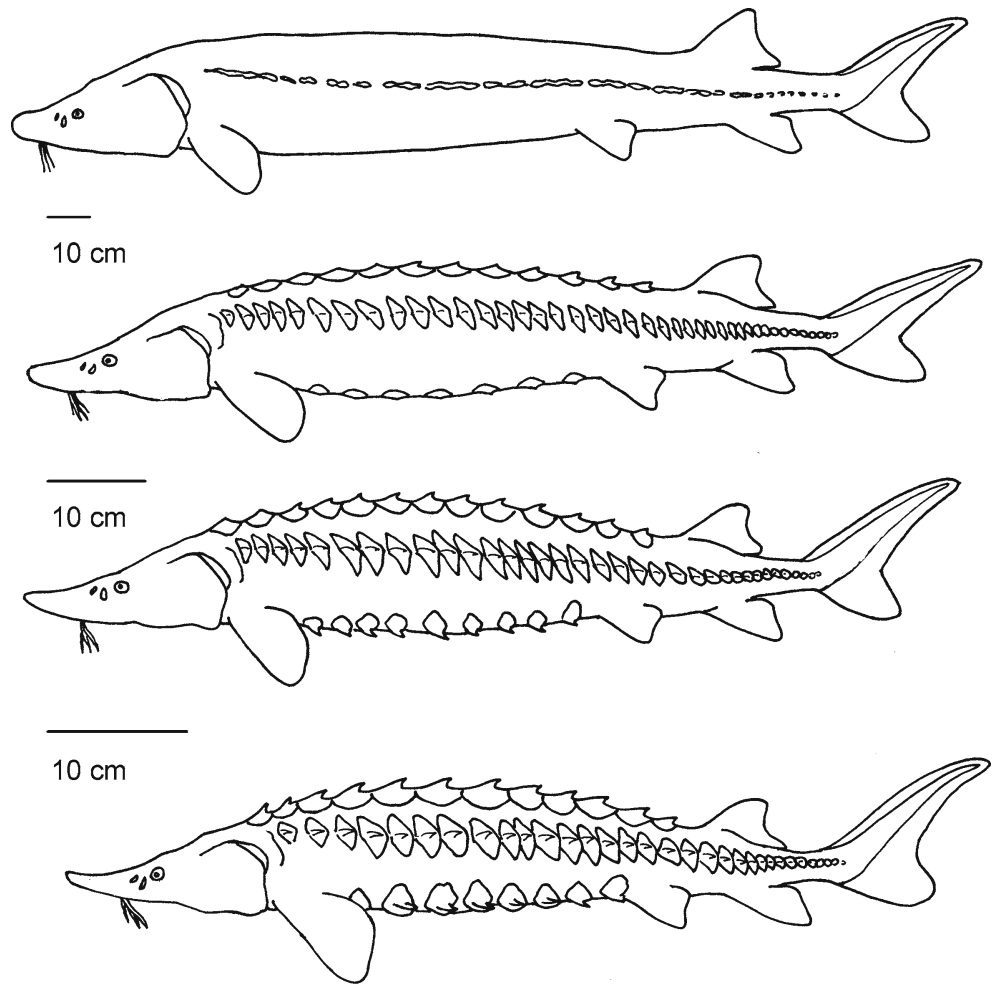

$10 \mathrm{~cm}$ 
Fig. 4 Armouring of the lake sturgeon skull

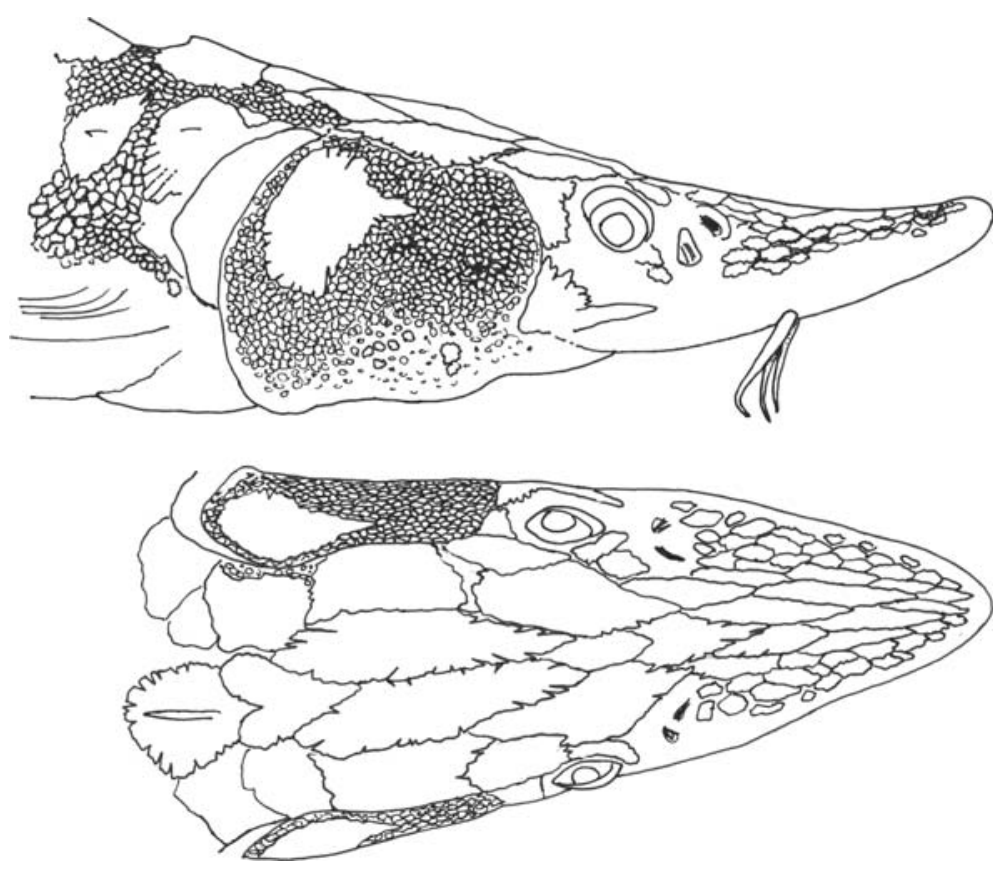

(e.g. Jollie 1980); however, only the skull structure of shortnose sturgeon has been well studied (Hilton and Bemis 1999). Although the lake sturgeon skull is comparatively less variable, Jollie (1980) noted considerable intraspecific and ontogenetic variation.

While the enodcranial elements of Acipenseridae may be useful in understanding some phylogenetic relationships within the group, they are generally too complex and variable for use in species identification. Fortunately, the number and arrangement of dermal plates on the dorsum and ventrum of the posterior trunk are much more species-specific and less subject to individual or ontogenetic variation. Although Vladykov and Greeley (1963) report that predorsal plates may be used for taxanomic identification, the postdorsal and preanal plates are most commonly used for this purpose. In lake sturgeon the postdorsal plates are typically seen as 1-2 unpaired elements (Vladykov and Greeley 1963; Peterson et al. 2003); however, the second predorsal may appear as a paired element in some individuals. The relatively large preanal plates always occur in single file and number 1-2 (Vecsei and Peterson 2004). These ossifications may be considered definitive in all cases except on very old individuals where they may be completely resorbed.

Body coloration of lake sturgeon is variable among stocks but is typically dark brown or dark gray dorsally with a similar but slightly lighter coloration on the lateral surfaces. The ventrum is typically white or cream-colored. Some individuals have gray or black pigmentation on the underside of the head, particularly on the lips and barbels (Harkness and Dymond 1961). Rarely, adults may exhibit white or milky blotches or spots on the lateral body surfaces. The dorsal and lateral scutes are typically the same color as the surrounding skin, although rare specimens may have slightly lighter lateral scutes or dark pigmentation on the lateral surfaces of the ventral scutes.

Although lake sturgeon exhibit considerable morphological ontogeny, the changes in color pattern from early juvenile to adulthood are among the most pronounced (Vladykov and Greeley 1963; Priegel and Wirth 1971; Peterson et al. 2003). In juveniles $<30 \mathrm{~cm}$, two large black saddles typically are present across the gray or brown dorsum and sides (Fig. 5). Black speckling on the upper surfaces of the body also is common, often producing a 'peppered' appearance on the 
Fig. 5 Basic morphology and coloration of juvenile lake sturgeon $(<30 \mathrm{~cm})$
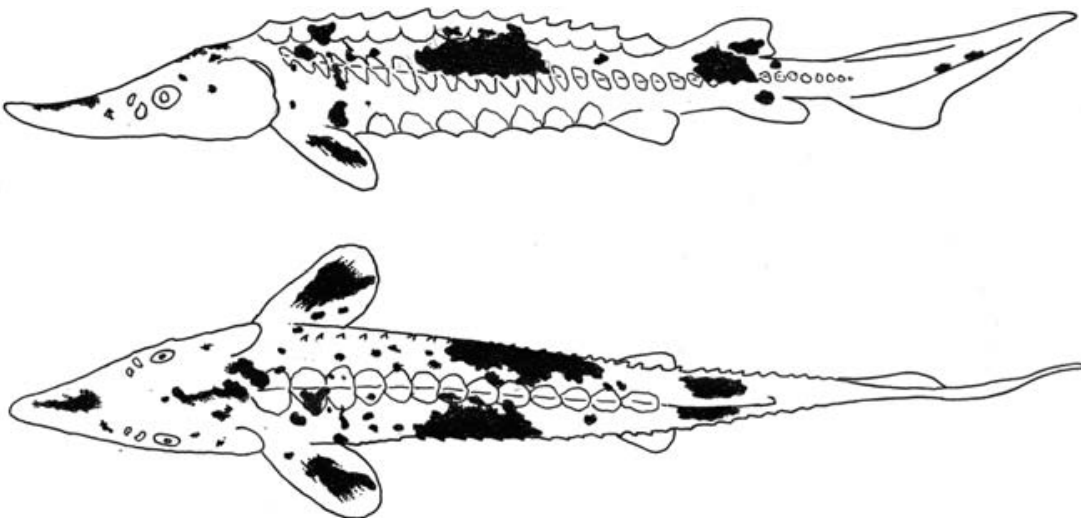

juveniles. Scutes and other dermal ossifications of juveniles are usually of the same color as the surrounding skin, but lateral scutes may sometimes be lighter (as in the adults). In 2-4 year old juveniles $(>60 \mathrm{~cm})$ the large saddle marks are lacking but the black speckling may persist into early adulthood.

\section{Distribution and legal status}

The current distribution of $A$. fulvescens includes three major North American drainages: the Mississippi, the Great Lakes, and the Hudson Bay (Priegel and Wirth 1971). The historic range of the species extended from the Canadian waters of the Hudson Bay in Saskatchewan and Manitoba, east to the St. Lawrence River estuary. To the south, US populations were found primarily in the Great Lakes and Mississippi River basins with smaller isolated populations occurring further south in the larger rivers of the Tennessee River and Ohio River drainages (Scott and Crossman 1973). Although found primarily in larger freshwater lakes and rivers, lake sturgeons are also native to the brackish waters of Hudson Bay and the St. Lawrence River estuary (Fig. 6) (Vladykov and Greeley 1963).

Currently, the lake sturgeon is not federally protected in either the US or Canada; however, the species was listed in 1975 under Appendix II of the Convention on International Trade of Endangered Species (CITES). Although this
Fig. 6 Historic distribution of lake sturgeon in North America (adapted from Scott and Crossman (1973), and CITES (2000))

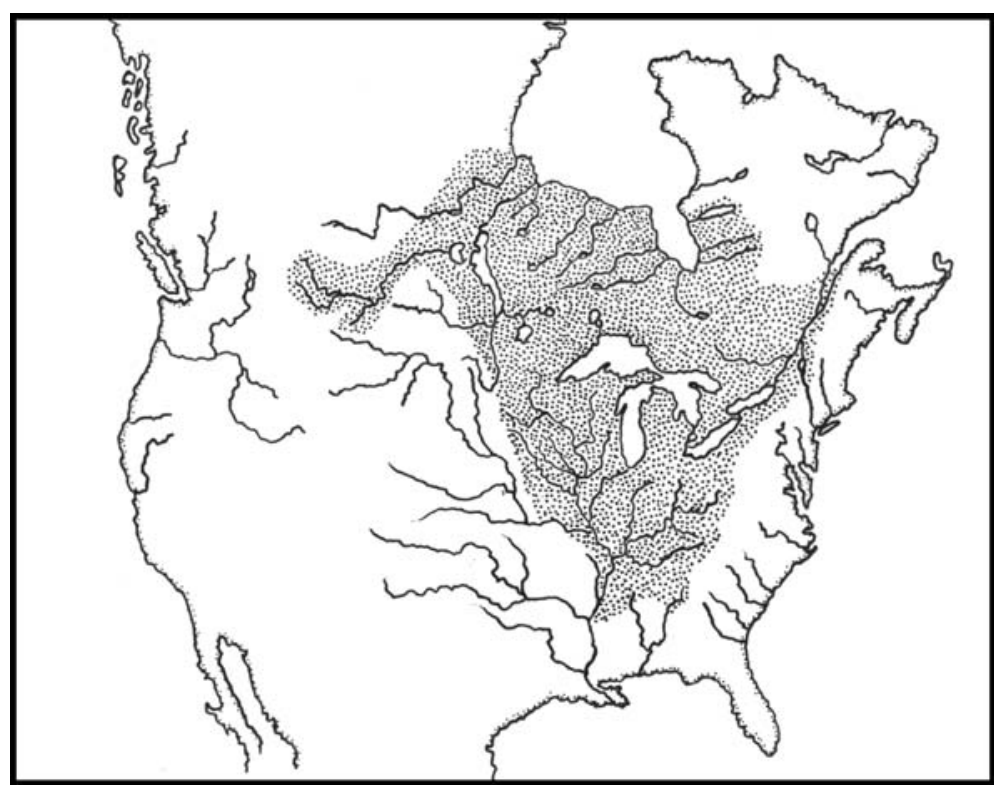


listing was temporarily suspended in 1983, it was reinstated in 1998. Within the US, the species receives various levels of protection at the state level. Populations in Iowa, Indiana, Illinois, Ohio, Missouri, Pennsylvania, Tennessee, and Vermont are considered endangered while those in Nebraska, New York, and Michigan are listed as threatened (Johnson 1987; Auer 2004; Leonard et al. 2004). In Canada, lake sturgeons are listed as threatened in Alberta, Manitoba, New Brunswick, Newfoundland, Ontario, Quebec, and Saskatchewan (Freedman et al. 2001; TRAFFIC North America 2002).

Despite the many anthropogenic factors that have decimated most populations, a few healthy populations still exist. The largest of these is probably that of the St. Lawrence River near Montreal where commercial fisheries in the 1980s and 1990s produced sustained annual harvests of 15,000-30,000 fish (Fortin et al. 1993). Recent studies by LaHaye et al. (1992) however, suggest that this population is actually comprised of at least three distinct stocks. In US waters, the largest remaining population is that of the Lake Winnebago System in central Wisconsin (Bruch 1999; Bruch and Binkowski 2002) where the species has been actively managed for the past 100 years. Recent studies by Thomas and Haas (2002) have shown that the largest remaining Great Lakes population is probably that of Lake St. Clair. All three of these populations support limited recreational fisheries, and some commercial fishing is permitted in both the St. Lawrence River and the Canadian waters of Lake St. Clair.

\section{Life history and ecology}

A first comprehensive summary of lake sturgeon life history was provided by Harkness and Dymond (1961). More recently, studies of lake sturgeon biology and management have come from Wisconsin, where sizeable populations have been re-established through careful management, restoration of spawning habitat, and judicious stocking programs (Priegle 1973; Priegle and Wirth 1975; Thuemler 1985; Kempinger 1988; Larson 1988; Bruch 1999; Bruch and Binkowski 2002). Many of these management efforts have been aided by recent investigations of new propagation and habitat restoration techniques (Ceskleba et al. 1985; Conte et al. 1988).

Spawning periodicity and fecundity

Lake sturgeon life history is characterized by rapid growth during a protracted juvenile stage, with first spawning typically delayed until age 1215 for males and 18-27 for females (Scott and Crossman 1973; Bruch 1999; Bruch et al. 2001). Studies of lake sturgeon physiology have shown that this delay in maturation results from an unusually disproportionate allocation of energy to somatic growth during the juvenile years (Beamish et al. 1996; LeBreton and Beamish 2004). This strategy has the evolutionary disadvantage of delaying reproduction, but it yields a compensatory advantage by providing both the time and energy needed to maximize size at first spawning. Because natural mortality is largely size-dependent, this reproductive strategy helps limit mortality to the earliest life stages, thereby increasing potential life span. As in other long-lived species, this strategy provides the adults with multiple reproductive opportunities spread over many years or even decades. In the absence of anthropogenic disturbance, this strategy conveys the selective advantage of minimizing any loss of fitness resulting from year-class failures in any one year when spawning conditions are poor (Crouse 1999).

Large size at first spawning also provides the advantage of increased fecundity in lake sturgeon, which is among the highest of all freshwater species in North America (Harkness and Dymond 1961; Scott and Crossman 1973). Although the number of eggs produced on a per-weight basis is variable, fecundity generally increases as a function of size with a typical adult female producing 49,000-667,000 eggs in each spawning year (Harkness and Dymond 1961; Priegel and Wirth 1971). Like many other demersal broadcast spawners, lake sturgeons benefit from their high fecundity by essentially overwhelming potential predators with the sheer numbers of offspring they produce. Unlike other fishes of this reproductive guild however, lake sturgeon also rely on their high 
fecundity to help maximize reproductive output during years of favorable spawning conditions (Beamesderfer and Farr 1997).

Although a large female lake sturgeon may spawn more than a million eggs in a single spawning season, the species' reproductive rate is inherently slow because of protracted spawning periodicity (Harkness and Dymond 1961). Typically, females spawn only once every 4-9 years, males every 1-3 years (Roussow 1957; Magnin 1966; Fortin et al. 1996). This low spawning frequency, coupled with a life span of up to 154 years (MacKay 1963), typically results in spawning runs consisting of 20 or more age classes in unexploited populations. The complex age-structure of such populations helps buffer them against short-term environmental disturbances-an important key to the species' evolutionary success. Unfortunately, this inherent population resilience is quickly eroded when spawning adults are exposed to excessive harvest.

\section{Spawning behavior}

Lake sturgeons spawn in spring, usually from mid-April to early June; however, several researchers have noted that males typically arrive at the spawning grounds before females. On the Wolf and Fox rivers for example, Bruch and Binkowski (2002) observed males at several spawning sites $1-2$ days before the females. Once females are present, spawning may begin as soon as water temperatures reach $10-15^{\circ} \mathrm{C}$ (Harkness and Dymond 1961; Kempinger 1988; Auer 1996b; Smith and King 2005); however, specific temperatures that trigger spawning are variable and depend on the ovarian cycles of individual females (Webb et al. 2001).

Studies of courtship behavior in lake sturgeon are rare, but a few authors have noted that males often produce drumming sounds in the presence of gravid females (Priegel and Worth 1971, 1974; Bruch and Binkowski 2002). During spawning, 2-8 males typically crowd individual females on each flank, frequently pounding her with their tales to stimulate egg release. These spawning bouts can be intense, but typically last only 1-2 minutes (Bruch and Binkowski 2002). The process is repeated several times with different males maneuvering into the group during each subsequent bout until the female is spent. Although this behavior leaves most fish in poor post-spawning condition, Bruch and Binkowski (2002) suggest that this polygamous mating system may help guarantee the highest number of possible mates for both sexes while minimizing the energy expended in finding them.

During spawning, females scatter their adhesive eggs widely over gravel or cobble substrates in water depths of $0.1-2 \mathrm{~m}$ (Priegel and Wirth 1974; Becker 1983; LaHaye et al. 1992; Auer and Baker 2002; Bruch and Binkowski 2002). Females usually complete spawning in 8-12 h, after which they leave the spawning area. Males however, may remain on the spawning site as long as a ripe female is present. Once all females have left a spawning site, males may move downstream until they find deeper water where they await the arrival of additional ripe females.

Successful spawning in lake sturgeon largely depends on the suitability of both flow and temperature regimes, but optimal spawning conditions may vary substantially among populations (Cooke et al. 2002; Jager et al. 2002). For most populations, optimal spawning habitat is found in the high-gradient reaches of large rivers with current velocities of $0.5-1.3 \mathrm{~m} / \mathrm{sec}$ and substrates of coarse gravel or cobble (Auer 1996a; McKineley et al. 1998); although, a few populations are known to spawn on rocky, wave-washed lake shores (Harkness and Dymond 1961; Carlson 1995). Regardless of the specific spawning habitat chosen, no parental care is given, and the adults typically migrate back downstream as soon as spawning has concluded (Harness and Dymond 1961; Kempinger 1988).

\section{Early life stages}
'Although morphological changes are con- tinuous, there are periods during which changes take place much more rapidly than at other times. Changes, especially marked during the period from one to two weeks after hatching, are almost in the nature of a metamorphosis.'
- Harkness and Dymond (1961) in: The lake sturgeon 
Eggs

Immature lake sturgeon eggs are yellowish and attached to a fatty ovarian mass without a covering membrane (Detlaf et al. 1993; Bruch et al. 2001). The fully-developed eggs are olivegreen, grey or black and measure $2.6-3.5 \mathrm{~mm}$ (Bajkov 1930; Harkness and Dymond 1961; Priegel and Wirth 1974; Becker 1983). Hatching of lake sturgeon eggs typically occurs after 8-14 days with rate of embryonic development depending on water temperature (Kempinger 1988). Developmental studies by Wang et al. (1985) show that at $15^{\circ} \mathrm{C}$, gastrulation occurs at $37 \mathrm{~h}$, neurulation at $77.7 \mathrm{~h}$, and heart formation at 118 h. Few studies have documented predation on lake sturgeon eggs; however, observations of Bruch and Binkowski (2002) suggest that male lake sturgeon may consume fertilized eggs while on the spawning grounds. Although directed studies are rare, lake sturgeon eggs are probably eaten by many fishes and invertebrates. In the Muskegon River of western Michigan, for example, stomachs from several brown trout (Salmo trutta) harvested in the recreational fishery were found to contain lake sturgeon eggs (P. Vecsei, personal observation).

\section{Larvae}

At hatching, the 9-11 mm yolk-sac larvae (or prolarvae) are poorly developed and many basic anatomical structures are barely discernable. The mouth is apparent only as an inward fold, the barbels as tiny stubs. At 17-18 mm however, both structures are well developed and clearly discernable. Other structures, including gills, fins, and lateral lines also develop late in the yolk-sac stage (Kempinger 1988). On live specimens $<15 \mathrm{~mm}$, the contrast between the transparent body and dark or olive-grey yolk sac is evident; however, dead or preserved specimens appear uniformly light grey (Vecsei and Peterson, personal observation). At $15 \mathrm{~mm}$, the yolk-sac larvae develop dark pigmentation, which becomes most prominent along the lateral portion of the head and trunk. At this stage, a dark spiral valve and anal plug also become apparent (Wang et al. 1985).
Newly hatched larvae are pelagic, negatively phototactic, and move about actively in search of suitable hiding places within the interstitial spaces of the rocky substrates where they were spawned (Harkness and Dymond 1961; Wang et al. 1985; Kempinger 1988). Within 13-19 days after hatching, the 17-18 $\mathrm{mm}$ larvae emerge from the substrate at night and rapidly disperse downstream, often drifting with the current for several kilometres before again settling on the river bottom (Kempinger 1988; LaHaye et al. 1992). Although the exact timing of this downstream dispersal is somewhat variable, a minimum water temperature of $16^{\circ} \mathrm{C}$ seems to trigger this behavior (Smith and King 2005).

The onset of exogenous feeding signals the transition from the prolarval to the larval stage. Kempinger (1988) noted that the anal plug is shed just prior to this transition when the larvae are about $22 \mathrm{~mm}$. The post-yolk sac larva is easily identified by a prominent lateral band that extends the entire length of its body, including the caudal fin. The trunk is pigmented in its entirety but is darkest along this mid-lateral band. The larval stage continues for several weeks until the start of the juvenile stage at about $400 \mathrm{~mm}$.

\section{Juveniles}

In lake sturgeon, the transition from the larval to juvenile stage is marked by the formation of all definitive adult structures except for the gonads, which remain undifferentiated for several years. The juvenile period is protracted and immature individuals may vary greatly in size and age. Like the adults, juveniles are thought to feed primarily on benthic invertebrates such as small crustacea, insect larvae, leeches, molluscs, and isopods (Harkness 1923; Wallus 1990; Chiasson et al. 1997). Information on the movements and habitats of juvenile lake sturgeon is scant; however, available data suggest that yearlings may gather in large schools in shallow river mouths or adjacent bays during late summer and fall (Priegel and Wirth 1974; Becker 1983; Wallus 1990). After their first year, juveniles are found in the same habitats as the adults (Priegel and Wirth 1974). 
Adults

\section{Age and growth}

Adult lake sturgeons are among the largest of North American freshwater fishes. Adult males typically measure $100-185 \mathrm{~cm}$ and weigh 11$30 \mathrm{~kg}$; adult females $130-215 \mathrm{~cm}$ and $25-100 \mathrm{~kg}$. Although larger specimens are now rare, numerous specimens $>100 \mathrm{~kg}$ were reported in historical records of Great Lakes fisheries. The largest documented specimen, taken from Lake Michigan in 1943, measured $241 \mathrm{~cm}$ and weighed $141 \mathrm{~kg}$ (Van Oosten 1956). Although lake sturgeon growth is quite variable even within a population, historical accounts suggest that average size tends to decrease in the southern portion of the range (Stearns and Atkinson 1953), presumably because water temperatures become too warm during summer months.

Age determination of most bony fishes is usually accomplished by counting inter-annual growth rings present in cross-sections of the sacular otoliths; however, this method is not preferred by most sturgeon researchers. Although the methodology is similar for sturgeons (Classen 1944; Currier 1951; Brennan and Cailliet 1991; Wilson 1987), the marginal pectoral fin ray is used instead because it is easier to collect and its removal is non-lethal (Roussow 1957; Rossiter et al. 1995). Typically, the annuli appear as widely separated bands in early years but these become increasingly crowded near the outer margins of the fin ray cross-sections. Hence, age determination in sturgeons becomes increasingly uncertain in older specimens (Keenlyne and Jenkins 1993). Rossiter et al. (1995) found that this method was easiest and most accurate for lake sturgeon up to age-15; and while age estimates of much older fish are frequently published, numerous studies have questioned their accuracy (Brennan and Cailliet 1991; Rien and Beamesderfer 1994).

\section{Food habits and feeding}

Lake sturgeons feed primarily on benthic invertebrates that they find using a combination of tactile, olfactory, chemosensory, and electrosensory receptors (Harkness and Dymond 1961; Binkowski and Doroshov 1985; Chiasson et al. 1997). Feeding is accomplished as the animal swims along the bottom with its barbels in contact with the substrate. As prey items are detected, they are sucked in by a rapid extension of the protractible mouth (Priegel and Wirth 1974; Vecsei and Peterson 2004). Inedible materials such as sand or silt, sucked are expelled through the mouth or gills, while food items are retained and crushed against the ridges of cartilaginous palate before being swallowed (Harkness and Dymond 1961; Priegel and Wirth 1974). Although benthic macroinvertebrates are the most important prey consumed, lake sturgeon diet varies considerably both spatially and temporally (Chiasson et al. 1997; Beamish et al. 1998). Prey items reported from lake sturgeon stomachs include leeches, snails, small clams, and small fishes, although when available, soft-bodied insect larvae may comprise up to $90 \%$ of the prey volume consumed (Bajkov 1930; Harkness 1923; Harkness and Dymond 1961; Priegel and Wirth 1974). Lake sturgeons forage actively throughout the year; however, feeding may slow during winter in northern portions of the range (Priegel and Wirth 1974).

\section{Habits and movements}

Habitat Lake sturgeons often migrate over great distances in search of food, suitable spawning habitat or simply to avoid seasonally unfavorable conditions (Auer 1996b; Bemis and Kynard 1997). However, habitat selection depends on availability and the specific requirements of each life stage. Young juveniles for example, often use deep $(>2 \mathrm{~m})$ pools within their natal streams for feeding and over-wintering; whereas, adults typically inhabit deepwater habitats of large lakes. Although adult lake sturgeons are rarely observed in non-spawning habitats, several studies suggest that they prefer depths of $<9 \mathrm{~m}$ during cooler months but will readily move to much deeper water in summer (Harkness and Dymond 1961; Priegel and Wirth 1974). Other studies suggest that these deep-water habitats may also be used for over wintering (Bajkov 
1930) or to avoid disturbance from intense boat traffic (Engel 1990).

Lake sturgeons can be found over a variety of substrate types, but prey abundance is undoubtedly an important factor in determining habitat selection (Harkness and Dymond 1961). In shallow lakes such as Lake Winnebago, Wisconsin, where water depths are $<7 \mathrm{~m}$, lake sturgeons occupy all depths (Priegel and Wirth 1971; Lyons and Kempinger 1992). In deeper lakes such as Black Lake, Michigan, however, adult fish are typically found at depths of 6-12 m (Hay-Chmielewski 1987). Although seasonal habitat selection in these inland systems is probably more influenced by water temperature, corroborative studies are lacking.

Migration Throughout their life cycle, lake sturgeons exhibit both random and non-random movements. Several studies have shown that most individuals move about randomly within an established home range of 10-14 km; however, some individuals seem to make longer unidirectional movements indicative of emigration (Harkness and Dymond 1961; Priegel and Wirth 1974; Larson 1988; Engel 1990). Early tagging studies from Wisconsin suggested that individuals with established home ranges rarely leave these areas except to spawn (Harkness and Dymond 1961; Priegel and Wirth 1974). Although lake sturgeons are known to migrate up to $200 \mathrm{~km}$ when returning to their natal streams, spawning-site fidelity in lake sturgeons has not been well studied, and the environmental cues that trigger and guide the fish during these migrations are unknown. Studies of imprinting in lake sturgeon have not been attempted, but many biologists believe that juveniles are able to recognize their natal stream within only a few months after hatching.

Gerbilskiy (1957) and Bemis and Kynard (1997) characterized sturgeon spawning migrations as either a 'one-step' or 'two-step' pattern. Species exhibiting one-step migrations typically migrate in spring and spawn within a few days of reaching their natal spawning grounds. Those following the two-step migration pattern typically begin their migrations in fall but overwinter in deep pools before spawning in the subsequent spring. These two distinct migration patterns are not only exhibited by different sturgeon species, but also by different races or subpopulations (Bemis and Kynard 1997). Within the Great Lakes, one-step migrations are well documented for most lake sturgeon populations including the Manistee (Peterson et al. 2002), Muskegon (Peterson and Vecsei 2004) and the Sturgeon (Auer 1996b) rivers. In Wisconsin tributaries of Lake Michigan however, Bruch and Binkowski (2002) found that both one-step and two-step migrations are typical of lake sturgeon populations spawning in the Fox and Wolf rivers. Regardless of which upstream migration pattern is used, adult lake sturgeon typically move rapidly downstream after spawning has concluded, eventually returning to a larger river or lake to replenish energy stores over the next several years before the next spawning cycle.

\section{Mechanisms leading to declines}

Commercial fisheries of the mid 19th Century dealt the first major blow to lake sturgeon populations throughout much of North America. Ironically, the species was widely regarded as 'nuisance bycatch' prior to 1860 , and most individuals were either used as pig feed, fertilizer or were simply discarded (Tody 1974). After 1860, the popularity and value of lake sturgeon grew rapidly once European demand for North American caviar exceeded the production from Atlantic sturgeon fisheries operating on the Delaware and Hudson rivers (Bogue 2000; Saffron 2002). The first dedicated commercial facility for processing lake sturgeon was established in 1868 by German immigrants (Bogue 2000). Located on the shores of Lake Erie in Sandusky, Ohio, the new plant used the traditional European processing methods to establish and exploit lucrative markets for almost every part of the fish. The flesh was smoked or sold fresh and the roe processed into fine caviar. Even the swim bladder was used to produce isinglass, paint additives, and a number of other valuable commercial products (Priegel and Wirth 1971; Scott and Crossman 1973).

Once new markets for lake sturgeon products had been established, targeted commercial fisheries grew rapidly. By 1925, lake sturgeon had 
become the most valuable commercial species in the Great Lakes, but by this time many stocks had already collapsed (Tody 1974). By 1928, commercial harvest of lake sturgeons had been banned throughout the Great Lakes except for a limited fishery that has persisted in the Canadian waters of lakes St. Clair and Huron. The US ban on commercial fishing for lake sturgeon has remained in effect to the present, except for a limited re-opening of the fishery from 1950-1970 in the Michigan waters of Lake Michigan.

The rapid boom and bust cycle of commercial lake sturgeon fisheries in the Great Lakes was typical of the many smaller inland fisheries operating in both the US and Canada (Harkness and Dymond 1961). On the Mississippi River for example, commercial landings declined from $113,046 \mathrm{~kg}$ in 1894 to $55,842 \mathrm{~kg}$ in 1899 - a decline of about $50 \%$ in only 5 years. By 1922, annual harvest had declined to only $3,178 \mathrm{~kg}$; and by 1931, lake sturgeon had disappeared completely from the commercial catch (Carlander 1954). A similar scenario unfolded in Canada where most inland populations suffered similar declines during the first decade of the 20th Century, although careful management and conservation have allowed a few limited fisheries to continue.

\section{Management approaches}

'Sturgeon: Unlawful to take from inland waters except with hook \& line. Unlawful to take more than 50 in any one day or have more than 100 in possession at any one time'.

- From the Michigan Fish \& Game regulations, 1913

Restoration of lake sturgeon populations to selfsustaining levels is a common goal shared by many contemporary state and provincial management agencies. Towards this end, the species receives varying levels of protection and, in some instances directed management, depending on the biological status of the various populations and local public support. Most traditional management approaches focus on regulations that prohibit or severely limit harvest (Johnson 1987).
Such programs are based on the assumption that reductions in fishing mortality will result in higher numbers of spawners, higher recruitment of juveniles, and ultimately, increased abundance of adults. However, several authors suggest that this approach alone is inadequate to recover lake sturgeon stocks that have been severely depressed by overfishing because of the species' low reproductive rate and also because spawning habitat for many populations has been either lost or degraded (Harkness and Dymond 1961; Priegel and Wirth 1975; Thuemler 1988). Hence, some management agencies have developed comprehensive restoration plans based on a combination of management practices. Although regulations are typically included in these plans, habitat restoration, stocking, and public education are used increasingly to help expedite recovery.

Regardless of which management practices are chosen, successful restoration of lake sturgeon requires a long-term approach because the protracted reproductive cycle of the species requires that many juvenile and adult year classes be established before a population can become selfsustaining (Noakes et al. 1999). Where populations have been extirpated, managers must first ensure that suitable habitat is still available and then develop innovative approaches to re-introduce and protect the stock as it is rebuilt over many years or even decades. Once established, populations must be carefully monitored and managed to prevent overharvest. Management of recreational lake sturgeon fisheries in both Wisconsin and Michigan has included size limits, bag limits, harvest caps, and closed seasons (Priegel 1973; Priegel and Wirth 1971, 1975, 1978; Baker 1980; Larson 1988; Bruch 1999). Although these regulations may help stabilize extant populations, they have not yet proven to be effective at rebuilding depressed stocks (Becker 1983).

Lake sturgeon management is perhaps more complex that that of other North America sturgeons because the species' native range spans several different states, provinces, and international boundary waters between the US and Canada (Williamson 2003).

In Canada, lake sturgeons are protected and managed by the provinces under the Federal 
Fisheries Act (Houston 1987). Alberta closed all commercial fisheries between 1940 and 1968 as did Manitoba in 1995 (Ferguson and Duckworth 1997). In Saskatchewan, a moratorium has been enforced since 1996; however, small commercial fisheries still operate in the Ontario waters of Lake Huron, Lake Nipigon, Lake St. Clair, Namakan Lake, Rainy Lake, and the Seine River (Brousseau 1987). From 1998 to 2000, the combined catch quota from these fisheries was $11,553 \mathrm{~kg}$. In Quebec, a commercial gill net season was restricted to the period of June 14October 31 to avoid harvest of ripe females. The annual catch quota since the mid 1990s has been approximately $150,000-200,000 \mathrm{~kg}$ with a total allowable catch of approximately 20,000-30,000 fish (Williamson 2003). There are presently no commercial fisheries for lake sturgeon in U.S. waters, where individual states maintain jurisdiction over their respective stocks. The largest annual recreational harvest is on Lake Winnebago, Wisconsin, where approximately 1,000 fish are taken annually in a limited-harvest spear fishery (Folz and Meyers 1985; Bruch 1999).

\section{Restoration}

Because the success of the lake sturgeon's life history strategy depends on delayed maturation and infrequent spawning over a long life span, the species is particularly vulnerable to overfishing (Boreman 1997; Crouse 1999). Although most populations are now protected, loss of habitat and degraded water quality continue to threaten many remaining stocks. In the Great Lakes for example, dams have been constructed on every known spawning tributary. Effective sturgeon fishways have been constructed on some low-head impoundments, and artificial spawning habitats have been successfully introduced in some rivers (Bruch 1998). However, the lack of effective fish passage systems around hydropower facilities (and other high-relief dams) continues to fragment habitat and degrade water quality on many river systems (Baxter 1977; Jager et al. 2001). Consequently, ongoing studies of fish passage structures specifically designed for lake sturgeon may hold the greatest promise for restoring populations where dams limit access to suitable spawning habitat.

Because many remnant sturgeon populations have not recovered despite decades of legal protections, the use of stocking to either reestablish or supplement existing stocks has become widespread. In recent years, lake sturgeons have been stocked as both fry and fingerlings in several states including Wisconsin, Missouri, Michigan, New York, Georgia, and Tennessee. Although recent studies have demonstrated the importance of using only native specimens in sturgeon stocking programs (Secor et al. 2002; Paragamin and Beamesderfer 2004), lack of suitable brood stock has prompted new interest in alternative stocking strategies. Among the most promising of these is an experimental method known as 'head start', in which naturally-spawned lake sturgeon larvae are captured from the wild and then transferred to a protective hatchery environment where they can be reared for several months before release back into their natal streams. Because environmental conditions within the hatchery can be carefully controlled, first-year survival of these fry is typically much higher than in the wild. When used over many spawning seasons, this technique can dramatically amplify annual recruitment of naturally produced juveniles by artificially increasing critical-period survival. Unlike traditional stocking programs that typically rely on only a few wild adults to produce entire cohorts, the use of a head-start program can increase juvenile abundance while avoiding the potential problem of inbreeding depression. Although the new practice is not completely free of some artificial selection, the method may provide an important tool for restoration of depleted populations where at least some spawning still occurs. The first known use of the head-start method for lake sturgeon restoration occurred on the Black River, Michigan, in 2001 (D. Peterson, unpublished data). Since the inception of this program, annual releases of head-start lake sturgeon fingerlings have helped restore lake sturgeon populations in the Black, Sturgeon, and Pigeon rivers of northern Michigan (http://www.michigandnr.com/fishstock/default.asp 2006). 


\section{Research direction}

The available literature on the biology and life history of lake sturgeon seems comprehensive. However, the lake sturgeon has been extirpated from the southern portion of its range and is uncommon or rare in much of its remaining range. Numerous studies are currently underway to assess remaining populations as a first step toward restoration. While these studies will undoubtedly provide the scientific basis for future management, identification of limiting factors is currently the most critical research need. Accordingly, investigations focusing on recruitment mechanisms and ecological links between habitat requirements and successful reproduction of lake sturgeons are high priority. To ensure the success of current restoration efforts, additional studies are needed to address existing knowledge gaps regarding critical habitat requirements of the various life stages. This will be of particularly importance in regions where lake sturgeon populations are being reintroduced through stocking.

\section{Outlook}

The outlook for lake sturgeon recovery rangewide is guardedly optimistic, thanks in part to renewed interest in the species, novel approaches to management, new opportunities to eliminate long-standing data gaps, and continued progress in habitat restoration. Recent emphasis on maintaining biodiversity has prompted several new management initiatives to 'bring back the natives'. This has been especially true for large, charismatic species and has contributed to the renewed interest in enhancing or restoring lake sturgeon populations range-wide. As a result, many state and federal agencies have initiated or are planning to initiate lake sturgeon restoration programs.

Novel approaches such as 'sturgeon head start' and similar initiatives have increased recruitment success of naturally spawned lake sturgeon. In instances where natural reproduction is insufficient to support head start programs, stream-side rearing facilities are now being used to help ensure that juveniles produced for stocking are properly imprinted on their receiving waters prior to their release. Improved husbandry techniques such as converting hatchery-reared lake sturgeon to $100 \%$ commercial feed (Kornberg and Peterson 2005) also promises to help restoration efforts by increasing pre- and post-stocking growth and survival of such individuals.

The emerging application of conservation genetics techniques to fishery science also may improve artificial propagation programs. For example, mating protocols that manipulate parental crosses to maximize available genetic diversity have been developed and used for other species. The adoption of these approaches for artificial propagation of lake sturgeons will increase the effective population size in instances where brood stock is limited; and in turn, produce larger numbers of individuals for stocking than would have been available otherwise.

The increase in stocking programs to augment or re-establish lake sturgeon populations has provided new opportunities to study lake sturgeon in the wild. These new opportunities will provide data that were unavailable previously because lake sturgeon populations were limited in size or distribution. As a result, many known gaps in our knowledge about lake sturgeon biology, ecology, and life history could not be previously evaluated because of a scarcity of fish and the inability to study them in the wild. This limitation is being removed as an increasing number of populations are established throughout the species' range.

Finally, as state and federal regulations intended to protect the environment are enacted and enforced, there has been a gradual improvement in lake sturgeon habitat quality and quantity. Though not yet available at historic levels, suitable habitat has increased, and with it the probability of success of the aforementioned restoration activities. Further, as increasing numbers of lake sturgeon populations are enhanced or restored and then studied, our understanding of how the species responds to habitat changes (positive and negative) should increase and allow for refinement of habitat mitigation and protection.

Clearly, the recent interest in lake sturgeon has helped the species and its long-term prospects for 
survival. Our guarded optimism, however, is not intended as an "all clear" regarding threats facing the species. Obviously, many threats still remain, and they will be diminished only by continued awareness of how anthropogenic activities affect lake sturgeon populations and continued efforts toward habitat preservation and restoration.

\section{References}

Antoniu-Murgoci A (1936a) Particularit_s anatomiques caract_risant les esp_ces des genres Huso et Acipenser des eaux roumaines. Compt Rend S_anc Acad Sci Roum 1:1-3

Antoniu-Murgoci A (1936b) Particularit_s anatomiques qui diff_rencient le genre Huso du genre Acipenser des eaux roumaines. Ann Sci Univ Jassy 23:94-103

Antoniu-Murgoci A (1942) Contributions a l'_tude des Acipenserid_s de Roumanie. Ann Sci Univ Jassy 2 Sci Natur 28:289-385

Auer NA (1996a) Response of spawning lake sturgeon to change in hydroelectric facility operation. Trans Am Fish Soc 125(1):66-77

Auer NA (1996b) Importance of habitat and migration to sturgeons with emphasis on lake sturgeon. Can J Fish Aquat Sci 53:152-160

Auer NA (1999) Lake sturgeon: A unique and imperilled species in the Great Lakes. In: Taylor WW, Ferreri CP (eds), Great lakes fisheries policy and management. A binational perspective. Michigan State University Press, pp 515-536

Auer NA (2004) Conservation. In: LeBreton GTO, Beamish FWH, McKinley RS (eds) Sturgeon and Paddlefish of North America. Kluwer Academic Publishers, pp 252-276

Auer NA, Baker EA (2002) Duration and drift of larval lake sturgeon in the Sturgeon River. Michigan J Appl Ichthyol 18(4-6):557-564

Bajkov A (1930) Fishing industry and fisheries investigations in the prairie provinces. Trans Am Fish Soc 60:215-237

Baker JP (1980) The distribution, ecology, and management of the lake sturgeon (Acipenser fulvescens Rafinesque) in Michigan. Michigan Department of Natural Resources, Fisheries Division. Fisheries Research Report. No. 1883, 95 pp

Baxter RM (1977) Environmental effects of dams and impoundments. Annu Rev Ecol Syst 8:255-283

Beamish FWH, Jebbink JA, Rossiter A, Noakes DLG (1996) Growth strategy of juvenile lake sturgeon (Acipenser fulvescens) in a northern river. Can J Fish Aquat Sci 53:481-489

Beamish FWH, Noakes DLG, Rossiter A (1998) Feeding ecology of juvenile Lake Sturgeon, Acipenser fulvescens, in Northern Ontario. Can Field Nat 112(3):459-468
Beamesderfer RCP, Farr RA (1997) Alternatives for the protection and restoration of sturgeons and their habitat. Environ Biol Fish 48(1-4):407-417

Becker GC (1983) Fishes of Wisconsin. The University of Wisconsin Press, Madison, WI, 1052 pp

Bemis WE, Kynard B (1997) Sturgeon rivers: an introduction to acipenseriform biogeography and life history. Environ Biol Fish 48:167-183

Bemis WE, Findeis EK, Grande L (1997) An overview of Acipenseriformes. Environ Biol Fish 48:25-71

Binkowski FP, Doroshov SI (eds) (1985) North American sturgeons: biology and aquaculture potential. Dr. W. Junk Publishers, Dordrecht, 163 pp

Birstein VJ, Doukakis P, DeSalle R (2002) Molecular phylogeny of Acipenseridae: nonmonophylyof Scaphirhynchinae. Copeia 2:287-301

Bogue MB (2000) Fishing the Great Lakes: An environmental history, 1783-1933. The University of Wisconsin Press, Madison WI, 443 pp

Boreman J (1997) Sensitivity of North American sturgeon and paddlefish to fishing mortality. Environ Biol Fish 48:399-405

Brennan JS, Cailliet GM (1991) Age determination and validation studies of white sturgeon, Acipenser transmontanus, in California. In: Williot P (ed) The Proceedings of the 1st International Symposium on the Sturgeon. CEMAGREF, Bordeaux, France

Brousseau CS (1987) The lake sturgeon (Acipenser fulvescens) in Ontario. In: Oliver CH (ed) Proceedings of a Workshop on the Lake Sturgeon (Acipenser fulvescens). Ontario Fisheries Technical Report Series No. 23. Ontario Ministry of Natural Resources, Toronto, ON, pp 2-9

Bruch RM (1998). Management and trade of lake sturgeon in North America. In: Williamson DFG, Benz G, Hoover CM (eds) Caviar and conservation: Status, management and trade of North American sturgeon and paddlefish. TRAFFIC North America Washington D.C. World Wildlife Fund

Bruch RM (1999) Management of lake sturgeon on the Winnebago System-long term impacts of harvest and regulations on population structure. J Appl Ichthyol 15:142-152

Bruch RM, Dick TA, Choudhury A (2001) A field guide for the identification of stages of gonad development in lake sturgeon, Acipenser fulvescens Rafinesque, with notes on lake sturgeon reproductive biology and management implications. Publication of Wisconsin Department of Natural Resources. Oshkosh and Sturgeon for Tomorrow. Appleton, WI, $38 \mathrm{pp}$

Bruch RM, Binkowski FP (2002) Spawning behaviour of lake sturgeon (Acipenser fulvescens). J Appl Ichthyol 18:570-579

Buckland F (1883) Natural history of British Fishes. London

Carlander HB (1954) A history of fish and fishing in the upper Mississippi River. Upper Mississippi River Conservation Committee, Rock Island, IL

Carlson DM (1995) Lake sturgeon waters and fisheries in New York State. J Great Lakes Res 21:35-41 
Ceskleba DG, AveLallemant S, Thuemler TF (1985) Artificial spawning and rearing of lake sturgeon, Acipenser fulvescens, in Wild Rose State Fish Hatchery, Wisconsin, 1982-1983. Environ Biol Fish 14(1):79-85

Chiasson WB, Noakes DLG, Beamish FWH (1997) Habitat, benthic prey, and distribution of juvenile lake sturgeon (Acipenser fulvescens) in northern Ontario rivers. Can J Fish Aquat Sci 54: 2866-2871

Classen TEA (1944) Estudio Bio-Estadistico del Esturion o-Sollo del Quadalquivir (Acipenser sturio L.) Instituto Espanol de Oceanografia, Madrid, Trabajo numero 19

Conte FS, Doroshov SI, Lutes PB, Strange EM (1988) Hatchery manual for the white sturgeon. Publication \#3322. University of California Press, Oakland, 104 pp

Cooke DW, Leach SD, Isely JJ (2002) Behaviour and lack of upstream passage of shortnose sturgeon at a hydroelectric facility and navigation lock complex. In: Van Winkle W, Anders PJ, Secor DH, Dixon DA (eds) Biology, management, and protection of North American Sturgeon. American Fisheries Society, Symposium 28, Bethesda, MD, pp 101-110

Crouse DT (1999) The consequences of delayed maturity in a human dominated world. In: Musick JA (ed), Life in the slow lane: ecology and coservation of long-lived marine animals. Am Fish Soc Symp 23, Bethesda, MD, pp 195-202

Currier JP (1951) The use of pectoral fin rays for determining age of sturgeon and other species of fish. Can Fish Culturist 11:10-18

Detlaf TA, Ginsburg AS, Schmalhausen OI (1993) Sturgeon fishes: developmental biology and aquaculture. Springer-Verlag, Berlin, 300 pp

Engel MP (1990) Population parameters of lake sturgeon in the St. Croix River with special reference to movements. Draft Summary Report, Wisconsin Department of Natural Resources, Madison, WI, $44 \mathrm{pp}$

Ferguson MM, Duckworth GA (1997) The status and distribution of lake sturgeon, Acipenser fulvescens, in the Canadian provinces of Manitoba, Ontario and Quebec: a genetic perspective. Environ Biol Fish 48:299-309

Findeis EK (1997) Osteology and phylogenetic interrelationships of sturgeons (Acipenseridae). Environ Biol Fish 48:73-126

Folz DJ, Meyers LS (1985) Management of the lake sturgeon, Acipenser fulvescens, population in the Lake Winnebago system, Wisconsin. In: Binkowski FP, Doroshov SI (eds) North American sturgeons: biology and aquaculture potential. Dr. W. Junk Publishers, Dordrecht, The Netherlands, pp 135-146

Fortin R, Mongeau JR, Desjardins G, Dumont P (1993) Movements and biooigcal statistics of lake sturgeon (Acipenser fulvescens) populations from the St. Lawrence and Ottawa River system, Quebec. Can J Zool 71:638-650

Fortin R, Dumont P, Guénette S (1996) Determinants of growth and body condition of lake sturgeon (Acipenser fulvescens). Can J Fish Aquat Sci 53:1150-1156
Freedman B, Roger L, Ewins P, Green DM (2001) Species at risk in Canada. In: Beazley K, Boardman R (eds) Politics of the wild: Canada and endangered species. Oxford University Press, ON, pp 26-48

Gerbilskiy NL (1957) Ways of development of the intraspecies biological differentiation, types of anadromous migrants, and a question of migration impulse in sturgeons. Uchenye Zapiski Leningradskogo Gosudarstvennogo Universiteta 228:11-31 (in Russian)

Grande L, Bemis WE 1996. Interrelationships of Acipenseriformes, with Comments on Chondrostei. In: Stiassny MLJ et al. (eds) Interrelationships of Fishes. Academic Press, pp 85-116

Harkness WJK (1923) The rate of growth and food of the lake sturgeon (Acipenser fulvescens LeSueur). University of Toronto Biological Studies Series 24, Publication of the Ontario Fisheries Research Lab 18

Harkness WJK, Dymond JR (1961) The lake sturgeon. Ontario Department of Lands and Forests, Fish and Wildlife Branch, Toronto, 97 pp

Hay-Chmielewski EM (1987) Habitat preferences and movement patterns of the lake sturgeon (Acipenser fulvescens) in Black Lake, Michigan. Michigan Department of Natural Resources, Fisheries Research Report 1949, Ann Arbor, MI

Hilton EJ, Bemis WE (1999) Skeletal variation in shortnose sturgeon (Acipenser brevirostrum) from the Connecticut River: Implications for comparative osteological studies of fossil and living fishes. In: Arratia G, Schultze HP (eds) Mesozoic FishesII-Systematics and Fossil Record. Munchen, Germany, pp 69-94

Hochleitner M, Vecsei P (2004) Identification key to sturgeons and paddlefish of North America. In: LeBreton GTO, Beamish FWH, McKinley RS (eds) Sturgeons and Paddlefish of North America. Fish and Fisheries Series, Kluwer Acadmeic Publishers, pp 315-318

Holey ME, Trudeau TN (eds) (2005) The state of Lake Michigan in 2000. Great Lakes Fisheries Commission Spec. Pub. 05-01

Houston JJ (1987) Status of lake sturgeon, Acipenser fulvescens, in Canada. Can Field-Nat 101:171-185

Jager HI, Van Winkle W, Chandler JA, Lepla KB, Bates P, Counihan TD (2002) A simulation study of factors Controlling White sturgeon recruitment in the Snake River. In: Van Winkle W, Anders PJ, Secor DH, Dixon DA (eds) Biology, management, and protection of North American sturgeon. American Fisheries Society, Symposium 28, Bethesda, MD, pp 127-150

Jager HI, Lepla K, Chandler J, Van Winkle W (2001) A theoretical study of river fragmentation by dams and its effects on other riverine fishes. Environ Biol Fish 60:347-361

Johnson JE (1987) Protected fishes of the United States and Canada. American Fisheries Society, Bethesda MD, $42 \mathrm{pp}$

Jollie M (1980) Development of head and pectoral girdle skeleton and scales in Acipenser. Copeia 1980:226-249

Keenlyne KD, Jenkins LG (1993) Age at sexual maturity of the pallid sturgeon. Trans Am Fish Soc 122(3):393-396 
Kempinger JJ (1988) Spawning and early life history of lake sturgeon in the Lake Winnebago system, Wisconsin. Am Fish Soc Symp 5:110-122

Kornberg J, Peterson D (2005) New methods for intensive culture of lake sturgeon in Georgia. Technical report to the Georgia Department of Natural Resources, Project F-75, 13 pp

LaHaye M, Branchaud A, Gendron M, Verdon R, Fortin R (1992) Reproduction, early life history, and characteristics of the spawning grounds of the lake sturgeon (Acipenser fulvescens) in Des Prairies and L'Assomption rivers, near Montreal, Quebec. Can J Zool 70:1681-1689

Larson T (1988) The lake sturgeon fishery of Lake Wisconsin, 1978-1985. Wisconsin Department of Natural Resources, Fish Management Report No. 36, Madison, $34 \mathrm{pp}$

LeBreton GTO, Beamish FWH (2004) Growth, Bioenergetics and age In: LeBreton GTO, Beamish FWH, McKinely RS (eds) Sturgeon and Paddlefish of North America. Kluwer Academic Publishers, pp 217-230

Leonard NJ, Taylor WW, Goddard C (2004) Multijurisdictional management of Lake Sturgeon in the Great Lakes and St. Lawrence River. In: LeBreton GTO, Beamish FWH, McKinley RS (eds) Sturgeons and Paddlefish of North America, Kluwer Academic Publishers, pp 231-251

Lyons J, Kempinger JJ (1992) Movements of adult lake sturgeon in the Lake Winnebago system. Wisconsin Department of Natural Resources. Publication No. RS-156-92

MacKay HH (1963) Fishes of Ontario. Ontario Department of Lands and Forests. Bryant Press Ltd., Toronto, $300 \mathrm{pp}$

Magnin E (1966) Recherches sur les cycles de reproduction des sturgeons Acipenser fulvescens Rafinesque. Annales de la Station Centrale d'Hydrobiologie appliquee 9:8-242

McKinley RS, Van Der Kraak G, Power G (1998) Seasonal migration and reproductive patterns in the lake sturgeon, Acipenser fulvescens, in the vicinity of hydroelectric stations in northern Ontario. Environ Biol Fish 51:245-256

Noakes DLG, Beamish FWH, Rossiter A (1999) Conservation implications of behaviour and growth of the lake sturgeon, Acipenser fulvescens, in northern Ontario. Environ Biol Fish 55:135-144

Paragamian VL, Beamesderfer RC (2004) Dilemma on the Kootenai River - the risk of extinction or When does the hatchery become the best option? Am Fish Soc Symp 44:377-385

Peterson DL, Gunderman B, Vecsei P (2002) Lake Sturgeon of the Manistee River: a current assessment of spawning stock size, age, and growth. In: Biology, management, and protection of North American sturgeon. Am Fish Soc Symp 28:175-183

Peterson DL, Vecsei P, Noakes DLG (2003) Threatened fishes of the world: Acipenser fulvescens Rafinesque, 1817 (Acipenseridae). Environ Biol Fish 68:174

Peterson DL, Vecsei P (2004) Lake Sturgeon of the Muskegon River: population dynamics and life history. Final Report to the Great Lakes Fishery Trust, $33 \mathrm{pp}$

Priegel GR (1973) Lake sturgeon management on the Menominee River. Wisconsin Department of Natural Resources, Madison. Technical Bulletin No. 67. $20 \mathrm{pp}$

Priegel GR, Wirth TL (1971) The lake sturgeon: it's life history, ecology and management. WI Dept. Nat. Res. Publication 240-7, Madison, WI, 17 pp

Priegel GR, Wirth TL (1975) Lake sturgeon harvest, growth, and recruitment in Lake Winnebago, Wisconsin. Wisconsin Department of Natural Resources, Madison. Technical Bulletin No. 83, 25 pp

Priegel GR, Wirth TL (1978) Lake sturgeon populations, growth, and exploitation in lakes Poygan, Winneconne, and Lake Butte Des Morts, Wisconsin. Wisconsin Department of Natural Resources, Madison. Technical Bulletin No. 107. 23 pp

Priegel GR, Wirth TL (1974) The lake sturgeon: it's life history, ecology and management. WI Department of Natural Resources Publication 4-3600 (74), Madison, WI

Rien TA, Beamesderfer RC (1994) Accuracy and precision of white sturgeon age estimates from pectoral fin rays. Trans Am Fish Soc 123:255-265

Rossiter A, Noakes DLG, Beamish FWH (1995) Validation of age estimation for the lake sturgeon. Trans Am Fish Soc 124:777-781

Roussow G (1957) Some considerations concerning sturgeon spawning periodicity. J Fish Res Board Canada 14:553-572

Saffron I (2002) Caviar: the strange history and uncertain future of the World's most coveted delicacy. Broadway Books, 288 pp

Scott WB, Crossman EJ (1973) Freshwater fishes of Canada. Bulletin 184, Fisheries Research Board of Canada, Ottawa, 966 pp

Secor DH, Anders PJ, Van Winkle W, Dixon DA (2002) Can we study sturgeons to extinction? What we do and don't know about the conservation of North American sturgeons. Am Fish Soc Symp 28:3-12

Smith KM, King DK (2005) Dynamics and extent of larval lake sturgeon Acipenser fulvescens drift in the Upper Black River, Michigan. J Appl Ichthyol 21:161-168

Stearns JL, Atkinson B (eds) (1953) Etowah Sturgeon, Hitchhicking Lampreys. Georgia Game and Fish Commission 1:9

Thomas MV, Haas RC (2002) Abundance, age structure, and spatial distribution of lake sturgeon Acipenser fulvescens in the St. Clair System Michigan. Department of Natural Resources Fisheries Research Report 2076

Thuemler TF (1985) The lake sturgeon, Acipenser fulvescens, in the Menominee River, Wisconsin-Michigan. Environ Biol Fish 14(1):73-78

Thuemler TF (1988) Movements of young lake sturgeons stocked in the Menominee River, Wisconsin. Am Fish Soc Symp 5:104-109

Tody WH (1974) Whitefish, sturgeon, and the early Michigan commercial fishery. Michigan Department of Natural Resources, Lansing MI, pp 45-60 
TRAFFIC North America (2002) Fishy business. TRAFFIC North America bulletin, Washington, DC, Volume 5(1)

Van Oosten J (1956) The lake sturgeon in our endangered wildlife. Nat Wildl Fed Washington, DC, pp 9-10

Vecsei P, Peterson DL (2004) Sturgeon ecomorphology: a descriptive approach. In: LeBreton GTO, Beamish FWH, McKinley RS (eds) Sturgeons and Paddlefish of North America. Kluwer Academic Publishers, pp 103-133

Vladykov VD, Greeley JR (1963) Order Acipenseroidei. In: Bigelow HB, Breeder CM, Cohen DM, Mead GW, Merriman D, Olsen YH, Schroeder WC, Schultz LP, Teevan J (eds) Fishes of the Western North Atlantic, Part Three, New Haven, pp 24-60

Wang YL, Binkowski FP, Doroshov SI (1985) Effect of temperature on early development of white and lake sturgeon, Acipenser transmontanus and A. fulvescens. Environ Biol Fish 14(1):43-50

Wallus R (1990) Family Acipenseridae. In: Wallus R, Simon TP, Yeager BL (eds) Reproductive biology and early life history of fishes in the Ohio River drainage, vol. 1. Acipenseridae through Esocidae. Tennessee Valley Authority, Chattanooga, TN, pp 29-46

Webb MAH, Van Eenennaam JP, Doroshov SI, Moberg GP (2001) Preliminary observations on the effects of holding temperature on reproductive performance of female white sturgeon, Acipenser transmontanus Richardson. Aquaculture 176:315-329

Williamson DF (2003) Caviar and conservation: status, management and trade of North American sturgeon and paddlefish. TRAFFIC North America, Washington DC, World Wildlife Fund

Wilson JA, McKinley RS (2004) Distribution, habitat and movements In: LeBreton, GTO, Beamish FWH, McKinley RS (eds) Sturgeon and paddlefish of North America. Kluwer Academic Publishers, pp 40-69

Wilson NC (1987) Age determination of lake sturgeon (Acipenser fulvescens) by use of the marginal pectoral fin ray. In: Proceeding of a workshop on the lake sturgeon (Acipenser fulvescens). Ontario Ministry of Natural Resources Fisheries Technical Report Series No.23, Toronto, ON, pp 77-83 